\title{
Water Stress- and Nutrient Solution-mediated Changes in Water Relations and Amino Acids, Organic Acids, and Sugars in Xylem Fluid of Prunus salicina and Lagerstroemia indica
}

\author{
Peter C. Andersen ${ }^{1}$, Brent V. Brodbeck ${ }^{2}$, and Russell F. Mizell, $111^{3}$ \\ North Florida Research and Education Center, University of Florida, Route 4, Box 4092, Monticello, \\ FL 32344 \\ Additional index words. crape myrtle, plum
}

\begin{abstract}
The effects and interactions of water stress and nutrient solution on water relations and concentrations of amino acids, organic acids and sugars in xylem fluid of 'Methley' plum (Prunus salicina Lindl.) and 'Carolina Beauty' crape myrtle (Lagerstroemia indica $\mathbf{L}$.) during midday were determined. Container-grown plants were irrigated with water or nutrient solution (i.e., osmolarity $=138 \mathrm{~mm}$ ) for 15 days, then irrigation was either continued or terminated for the next 5 days. The experiments were analyzed as factorial designs for each species separately, with the nutrient solution and irrigation status the last 5 days as the main factors. Xylem fluid tension increased $\approx 2$ - to 3-fold and leaf conductance to water vapor and transpiration were reduced $\approx \mathbf{1 0}$-fold by withholding irrigation for both species; plant water relations of $L$. indica were also influenced by the nutrient solution. For both species, the osmolarity of xylem fluid was not altered by withholding irrigation. The predominant organic compounds quantified in both species were amides (i.e., glutamine and asparagine), arginine, and citric and malic acids. Sugars represented a small proportion (i.e., generally $\leq 1 \%$ ) of total osmolarity. Irrigation altered the chemical profile of amino acids and organic acids to a greater degree than the nutrient solution. Water stress induced a 3-fold increase in total organic acids in xylem fluid of both species. The osmolarity and the concentration of most organic compounds in xylem fluid of $P$. salicina were not significantly affected by the nutrient solution. Arginine increased markedly in concentration by withholding irrigation or with the application of nutrient solution for $\boldsymbol{L}$. indica. The concentration of most organic compounds did not vary greatly in response to variations in soil water or nutrient status. In conclusion, soil water-or nutrient-mediated changes in plant water relations exceeded changes in xylem fluid chemistry.
\end{abstract}

Xylem vessels serve as a major conduit for the delivery of inorganic ions and certain organic compounds to plant tissues. Xylem fluid is extremely dilute (i.e.,>95\% water) and consists primarily of amino acids, organic acids and inorganic ions (Andersen and Brodbeck, 1989a-c, 1991; Andersen et al., 1989, 1992; Clark et al., 1986). Although the concentration of solutes in xylem fluid is low, a large quantity of solute is transported in xylem fluid due to the large amount of water typically transpired by mesophytic plants. Despite the importance of xylem fluid to plant nutrient status and to leaf and shoot physiology, there have been relatively few attempts to characterize the influence of environmental stresses on the chemistry of xylem fluid.

Soil water and soil fertility status may drastically alter the concentration of organic compounds in foliar tissue (Boggess et al., 1976; Good and Zaplachinski, 1994; Rabe 1990; van Rensburg et al., 1993; Voetberg and Sharp, 1991). Rabe ( 1990) reviewed the influence of numerous abiotic and biotic stresses on the composition of $\mathrm{N}$-containing compounds in plants. The amino compounds most often accumulated in foliar tissue as a function of stress include glutamine, asparagine, arginine, proline, citrulline, and ornithine. It is not known, however, to what extent the chemical

Received for publication 15 Apr. 1994. Accepted for publication 8 Aug. 1994. Univ. of Florida Agricultural Experiment Station Journal series no. R-03757. Use of trade names does not imply endorsement of products named nor criticism of similar products not mentioned. The cost of publishing this paper was defrayed in part by the payment of page charges.Underpostal regulations, this paper therefore must be hereby marked advertisement solely to indicate this fact.

'Professor of horticulture.

${ }^{2}$ Senior biologist.

${ }^{3}$ Professor of entomology. compounds derived from xylem fluid contribute to stress-induced changes in the chemical profile of foliar tissue.

Evidence derived from plants exuding xylem fluid under positive pressure has been consistent with the concept that the composition of xylem fluid is regulated by the plant and is not greatly influenced by the composition of the rhizosphere. Fertilization during the dormant season had a minimal influence on the chemistry of xylem fluid during budbreak of several Vitis species. (Andersen and Brodbeck, 1991; Roubelakis-Angelakis and Kliewer, 1979) and kiwi (Clark et al., 1986). Andersen and Brodbeck (1991) found no difference in the osmolarity of xylem fluid of bleeding $V$. rotundifolia despite irrigation with $3 \mathrm{x}$ Hoagland's solution, although total water and solute flux were increased 3-fold compared to plants irrigated with water. Few differences in the concentration of organic and inorganic constituents in xylem fluid of Vitis spp. before budbreak occurred after the application of fertilizer in the field (Andersen and Brodbeck, 1991; Roubelakis-Angelakis and Kliewer, 1979). The potential contribution of solutes derived from the xylem fluid during periods of growth and positive root pressure is relevant to studies involving nutrient partitioning or stress-induced osmotic adjustment in plant tissue. These data may also be useful for developing and understanding $\mathrm{C}$ and $\mathrm{N}$ budgets.

Our objectives were to test the effects and the interaction of water stress and of soil applied nutrients on plant water relations and the concentration of amino acids, organic acids, and sugars in the xylem fluid of two woody species Prunus salicina and Lagerstroemia indica, which were chosen since they are in different families and have xylem fluid with markedly different profiles of organic compounds (Andersen et al., 1989). 


\section{Materials and Methods}

Plant material. In March 1989, P. salicina 'Methley' and $L$. indica 'Carolina Beauty' were potted in 12-liter containers with media consisting of 3 pine bark : 1 Canadian sphagnum peat : 1 sand. One cubic meter of medium was amended with $6.1 \mathrm{~kg}$ dolomite, $2.2 \mathrm{~kg}$ superphosphate, $0.9 \mathrm{~kg}$ Micromax (12S-0.1B$0.5 \mathrm{Cu}-12 \mathrm{Fe}-2.5 \mathrm{Mn}-.5 \mathrm{Mo}-12 \mathrm{Zn})$, and $5.9 \mathrm{~kg}$ Osmocote $18-\mathrm{N}-$ 2.6P-10K (Grace Sierra Corp., Milpitas, Calif.); initial medium $\mathrm{pH}$ was 5.6. Plants were supplied with overhead irrigation twice daily until $14 \mathrm{July,}$ at which time they were transported to a rainproof shelter covered with $6 \mathrm{ml}$ clear polyethylene. Twentyeight plants of each species were selected for uniform size. From 14 to 28 July, one-half of the plants was irrigated with $500 \mathrm{ml}$ tap water or with triple-strength Peters soluble fertilizer $20 \mathrm{~N}-8.2 \mathrm{P}-$ 16.6K (Grace Sierra Corp.) twice daily. The nutrient solution was composed of ammonia (30 mM), nitrate (47 mm), urea (38 mM), superphosphate $(14 \mathrm{~mm})$, and potash $(30 \mathrm{~mm})$. Total osmolarity was $138 \mathrm{~mm}$. On July 28, irrigation was terminated for one-half of the plants for 5 days. On 2 Aug., plant water status was determined and xylem fluid was extracted for quantification of amino acids, organic acids, and sugars.

Thus, the four treatments were 1) irrigation with water for 20 days (well-watered treatment); 2) irrigation with nutrient solution for 20 days (nutrient solution treatment); 3) irrigation with nutrient solution for 15 days which was then discontinued for 5 days (nutrient solution/water-stress treatment); 4) irrigation with water for 15 days which was then discontinued for 5 days (water-stress treatment).

Plant water relations. Leaf conductance to water vapor (g,) and transpiration rates (E) were measured on two recently expanded leaves of each plant with a steady-state porometer (model 1600M; LI-COR, Lincoln, Neb.) between 1100 and 1400 HR. Air temperature was 29 to $33 \mathrm{C}$ and relative humidity was $70 \%$ to $80 \%$ during the measurement period.

Leaves were placed in the leaf chamber for 1 minor until near steady-state conditions of $\mathrm{H}_{2} \mathrm{O}$ vapor exchange were achieved. Water vapor exchange was measured on abaxial leaf surfaces since adaxial $g_{1}$ was negligible. Measurements were recorded when photosynthetic photon flux exceeded $1000 \mu \mathrm{mol} \cdot \mathrm{m}^{-2} \cdot \mathrm{s}^{-1}$. Several minutes after measurements of leaf $\mathrm{H}_{2} \mathrm{O}$ vapor exchange, xylem fluid tension was measured on one or two $25-$ to $35-\mathrm{cm}$ stem segments of each of seven plants per treatment with a pressure chamber apparatus (model 600; Plant Moisture Stress Corp.,
Corvallis, Ore.) (Scholander et al., 1965). Tissue exterior to the xylem was removed from the 2- to 4- $\mathrm{cm}$ stem section protruding from the chamber before measurement of xylem tension and collection of xylem fluid.

Collection of xylem fluid and chemical analyses. After recording the xylem tension, the pressure was increased 0.5 MPa higher than the balance pressure for $90 \mathrm{sec}$ (Andersen et al., 1993; Berger et al., 1994). Xylem fluid was collected in 1.5-ml Eppendorf tubes, sealed, and placed on ice. Total osmolality of xylem fluid was determined with a vapor-pressure osmometer (model 5500; Wescor, Logan, Utah). Osmolality and osmolarity are virtually identical for dilute samples; hence, to facilitate comparison, concentrations of organic compounds will be expressed as osmolarity (mM). Preliminary experiments conducted on shoots of $P$. persica (L.) Batsch and $L$. indica have shown that the osmolarity of xylem fluid was not significantly altered in samples collected from 0 to 2 min after pressurization. Samples were stored at $-20 \mathrm{C}$ for several months before chemical analyses. Samples were thawed and centrifuged at $1200 \times \mathrm{g}$ through a 10,000 MW filter (Millipore Corp., Bedford, Mass.). Filtrate was divided into two subsamples for determination of amino acids and of organic acids and sugars (Andersen et al., 1993). The quantity of sample was insufficient for a comprehensive analysis of the chemical profile of inorganic ions.

Amino acids were analyzed following hydrolysis with constant boiling (110C) $6 \mathrm{M} \mathrm{HC1}$ for $24 \mathrm{~h}$ under $\mathrm{N}_{2}$. Samples were lyophilized and one hundred@ of 2 ethanol: 2 triethanolamine (TEA) $: 1 \mathrm{H}_{2} \mathrm{O}$ were added to each sample before drying under vacuum. Precolumn derivatization was completed by adding $20 \mu \mathrm{l}$ of 7 ethanol : 1 TEA : $1 \mathrm{H}_{2} \mathrm{O}: 1$ phenylisothiocyanate under $\mathrm{N}_{2}$ atmosphere for $20 \mathrm{~min}$. Amino acids were analyzed via a Waters high-performance liquid chromatography (HPLC) gradient system equipped with an ultraviolet (UV) detector and Pico Tag column (Waters Division Millipore Corp., Milliford, Mass.). The eluent consisted of $5 \mathrm{~mm}$ sodium phosphate buffer and $6 \%$ acetonitrile. Detection was at $254 \mathrm{~nm}$.

Organic acids were analyzed on a Waters HPLC system and a variable-wavelength UV detector (Beckman Corp., San Roman, Calif.). Samples in $0.015 \mathrm{mM} \mathrm{H}_{2} \mathrm{~S} \mathrm{O}_{4}$ buffer were run isocratically at $37 \mathrm{C}$ through an Ion-300 polymeric cation exchange column (Interaction Corp., San Jose, Calif.). Detection was at $214 \mathrm{~nm}$.

Sugars were analyzed with the HPLC system and detected with a Dionex Pulse Amperometric detector equipped with a gold electrode (Dionex Corp., Sunnyvale, Calif.). Pulse settings were

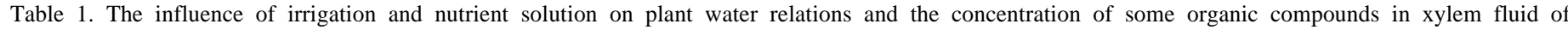
Prunus salicina. Treatment designation. $\mathrm{t}=$ irrigated with water for 20 days (well-watered treatment); $++=$ irrigated with nutrient solution for 20 days (nutrient solution treatment),+= nutrient solution for 15 days which was terminated for the final 5 days (nutrient solution/water-stress treatment), -- = irrigated with water for 15 days which was terminated for the final 5 days (water-stress treatment).

\begin{tabular}{|c|c|c|c|c|c|c|c|c|}
\hline \multirow{2}{*}{$\begin{array}{l}\text { Dependent } \\
\text { variable }\end{array}$} & \multirow{2}{*}{$\begin{array}{l}\text { Irrigation }(\mathrm{I}) \\
\text { Nutrient solution }\end{array}$} & \multirow{2}{*}{$\begin{array}{l}+ \\
\text { J) }-\end{array}$} & \multirow{2}{*}{$\begin{array}{l}+ \\
+\end{array}$} & \multirow{2}{*}{$\begin{array}{l}- \\
+\end{array}$} & \multirow{2}{*}{-} & \multicolumn{3}{|c|}{ Significance $^{z}$} \\
\hline & & & & & & $\mathrm{T}$ & $\mathrm{N}$ & $\mathrm{I} \times \mathrm{N}$ \\
\hline \multirow{3}{*}{\multicolumn{2}{|c|}{$\begin{array}{l}\text { Xylem tension }(\mathrm{MPa}) \\
\text { Leaf conductance }\left(\mathrm{mol} \cdot \mathrm{m}^{-2} \cdot \mathrm{s}^{-1}\right) \\
\text { Transpiration }\left(\mathrm{mmol} \cdot \mathrm{m}^{-2} \cdot \mathrm{s}^{-1}\right)\end{array}$}} & 0.66 & 0.74 & 1.60 & 2.14 & \multirow{2}{*}{$\begin{array}{c}* \\
* * *\end{array}$} & NS & \multirow{2}{*}{$\begin{array}{l}\text { NS } \\
\text { NS }\end{array}$} \\
\hline & & 0.203 & 0.198 & 0.041 & 0.021 & & NS & \\
\hline & & 6.58 & 5.24 & 1.44 & 0.83 & $* * *$ & NS & NS \\
\hline \multicolumn{2}{|c|}{ Total osmolarity (mM) } & 26.0 & 28.0 & 40.0 & 31.0 & NS & NS & NS \\
\hline \multicolumn{2}{|c|}{ Amino acids (mM) } & 2.32 & 2.67 & 3.09 & 3.17 & \multirow{2}{*}{$\begin{array}{l}\mathrm{NS} \\
* * *\end{array}$} & NS & NS \\
\hline \multicolumn{2}{|c|}{ Organic acids (mM) } & 1.18 & 0.93 & 2.47 & 3.44 & & NS & NS \\
\hline sugars $(\mathrm{mm}$ & & 0.15 & 0.16 & 0.26 & 0.23 & \multirow{2}{*}{$\begin{array}{l}\mathrm{NS} \\
* *\end{array}$} & NS & NS \\
\hline Total organ & pounds (mM) & 3.64 & 3.75 & 5.81 & 6.84 & & NS & NS \\
\hline \multicolumn{2}{|c|}{ Organic N (mM) } & 3.69 & 4.42 & 5.13 & 5.17 & \multirow{2}{*}{$\begin{array}{l}\mathrm{NS} \\
* * *\end{array}$} & NS & NS \\
\hline \multicolumn{2}{|c|}{ Organic $\mathrm{N}: \mathrm{C}$} & 0.258 & 0.308 & 0.210 & 0.186 & & NS & NS \\
\hline
\end{tabular}

",***," * Nonsignificant or significant at $P \leq 0.05,0.01$, or 0.001 , respectively. 


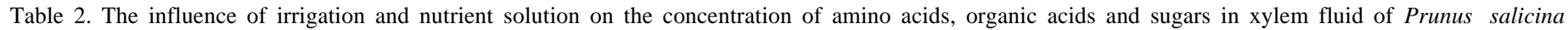
'Methley'. Treatment designation:+-= irrigated with water for 20 days (well-watered treatment);++ = irrigated with nutrient solution for 20 days (nutrient solution treatment); -+= nutrient solution for 15 days which was terminated for the final 5 days (nutrient solution/water-stress treatment); = irrigated with water for 15 days which was terminated for the final 5 days (water-stress treatment).

\begin{tabular}{|c|c|c|c|c|c|c|c|}
\hline \multirow[b]{2}{*}{ Dependent variable } & \multirow{2}{*}{$\begin{array}{l}\text { Irrigation }(\mathrm{I}) \\
\text { Nutrient solution }(\mathrm{N})\end{array}$} & $\begin{array}{l}+ \\
+\end{array}$ & $\begin{array}{l}- \\
+\end{array}$ & - & \multicolumn{3}{|c|}{ Significance } \\
\hline & & \multicolumn{2}{|c|}{ Concn $(\mu \mathrm{M})$} & & $\mathrm{I}$ & $\mathrm{N}$ & $\mathrm{I} \times \mathrm{N}$ \\
\hline \multicolumn{8}{|l|}{ Amino acid } \\
\hline ASN & 937 & 1191 & 1317 & 1350 & NS & NS & NS \\
\hline ASP & 234 & 118 & 180 & 381 & $-*$ & $* *$ & NS \\
\hline GLU & 49 & 57 & 4599 & NS & NS & $*$ & \\
\hline GLN & 87 & 139 & 182 & 148 & NS & $\mathrm{NS}$ & NS \\
\hline SER & 14 & 26 & 44 & 63 & $*$ & NS & NS \\
\hline GLY & 1 & 3 & 2 & 3 & NS & NS & NS \\
\hline HIS & 47 & 67 & 9 & 116 & $*$ & NS & NS \\
\hline ARG & 122 & 130 & 171 & 121 & NS & NS & NS \\
\hline ALA & 485 & 559 & 481 & 374 & $\mathrm{NS}$ & NS & NS \\
\hline THR & 90 & 84 & 122 & 125 & NS & NS & NS \\
\hline PRO & 84 & 94 & 116 & 111 & NS & $\mathrm{NS}$ & NS \\
\hline TYR & 14 & 15 & 32 & 14 & $\mathrm{NS}$ & $\mathrm{NS}$ & NS \\
\hline VAL & 56 & 57 & 160 & 115 & NS & NS & NS \\
\hline CYS & 26 & 8 & 19 & 15 & $\mathrm{NS}$ & NS & NS \\
\hline MET & 20 & 28 & 24 & 20 & NS & NS & NS \\
\hline ILE & 17 & 28 & 43 & 36 & $\mathrm{NS}$ & NS & NS \\
\hline LEU & 17 & 27 & 31 & 43 & $\mathrm{NS}$ & $\mathrm{NS}$ & NS \\
\hline PHE & 4 & 7 & 9 & 12 & $* *$ & NS & $*$ \\
\hline LYS & 11 & 28 & 19 & 24 & $\mathrm{NS}$ & $\mathrm{NS}$ & NS \\
\hline \multicolumn{8}{|l|}{ Organic acid } \\
\hline $\mathrm{OX}$ & 9 & 10 & 20 & 23 & $\mathrm{NS}$ & $\mathrm{NS}$ & NS \\
\hline CIT & 165 & 157 & 419 & 358 & $* * *$ & NS & NS \\
\hline MAL & 908 & 658 & 1810 & 2972 & $* * *$ & * & NS \\
\hline SUC & 74 & 91 & 169 & 50 & NS & $*$ & NS \\
\hline FUM & 17 & 12 & 28 & 29 & $*$ & $\mathrm{NS}$ & NS \\
\hline \multicolumn{8}{|l|}{ sugar } \\
\hline SUCR & 11 & 9 & 13 & 42 & $\mathrm{NS}$ & $\mathrm{NS}$ & $\mathrm{NS}$ \\
\hline FRUC & 9 & 75 & 116 & 85 & NS & $\mathrm{NS}$ & NS \\
\hline GLUC & 73 & 73 & 131 & 99 & NS & NS & NS \\
\hline
\end{tabular}

established at $0.6,0.07$, and $-0.8 \mathrm{mV}$ for 120,120 , and 300 milliseconds, respectively. Sugars were analyzed using $100 \mathrm{~mm}$ sodium phosphate buffer run isocratically through a Dionex IonPac ion-exchange column.

Subsets of nonhydrolyzed samples were used for two additional analyses. Since hydrolysis resulted in delamination, the first subset was used for the quantification of the ratio of the amides to their respective acids. The second subset was used for a more accurate quantification of succinic acid since coelution with an unknown compound occurred with normal UV detection procedures. In this case, quantification was facilitated with a Beckman 168 diode array detector scanning from 200 to $320 \mathrm{~nm}$.

Organic $\mathrm{N}$ and $\mathrm{C}$ were calculated from the concentration of each amino acid, organic acid, and sugar detected. Total organic compounds represent the sum of amino acids, organic acids, and sugars quantified.

Statistics. The experiment was designed and analyzed as a $2 \times 2$ factorial analysis of variance with water and nutrient solution as the two main factors. Species were analyzed separately. All seven plants of each treatment for each species were used for the analyses of plant water relation variables; however, only four replications from each treatment were analyzed chemically and subjected to statistical analyses of xylem fluid chemistry.

\section{Results}

Plant water relations were more greatly influenced by irrigation than concentration of organic compounds in xylem fluid of both species (Tables 1-4). Application of nutrient solution to $P$. salicina did not alter plant water relations, total osmolarity, or any class of organic compounds (Table 1). The nutrient solution affected plant water relations, osmolarity, and the concentration of organic $\mathrm{N}$ in xylem fluid of $L$. indica, although the chemical variables were more strongly influenced by withholding water (Tables 3 and 4).

Xylem tension of both species was $\approx 0.65$ to $2.15 \mathrm{MPa}$ for the well-watered and water-stress treatments, respectively (Tables 1 and 3). The 3-fold increase in xylem tension resulted in wilting of expanding leaves, yet at the termination of the experiment all plants recovered and resumed growth. The water-stress treatment was associated with a leaf conductance $\left(\mathrm{g}_{1}\right)$ of only 0.021 $\mathrm{mol} \cdot \mathrm{m}^{-2} \cdot \mathrm{s}^{-1}$ compared to $>0.20 \mathrm{mmol} \cdot \mathrm{m}^{-2} \cdot \mathrm{s}^{-1}$ for the well-watered treatment; transpiration also declined by an order of magnitude for both species. The nutrient solution/water-stress treatment resulted in $g_{1}$ and $E \approx 1.5$ - to 2 -fold greater than those of the water-stress treatments.

Osmolarity of xylem fluid was not significantly influenced by withholding irrigation from either species (Tables 1 and 3). How- 


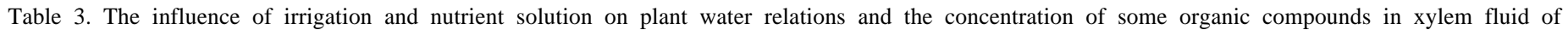
Lagerstroemia indica. Treatment designation:+-= irrigated with water for 20 days (well-watered treatment);++ = irrigated with nutrient solution for 20 days (nutrient solution treatment);-+= nutrient solution for 15 days which was terminated for the final 5 days (nutrient solution/water-stress treatment); -- = irrigated with water for 15 days which was terminated for the final 5 days (water-stress treatment).

\begin{tabular}{|c|c|c|c|c|c|c|c|c|}
\hline \multirow{2}{*}{$\begin{array}{l}\text { Dependent } \\
\text { variable }\end{array}$} & \multirow{2}{*}{$\begin{array}{ll}\text { Irrigation }(\mathrm{I}) \\
\text { Nutrient } & \text { solution }(\mathrm{N})\end{array}$} & \multirow{2}{*}{+} & \multirow{2}{*}{$\begin{array}{l}+ \\
+\end{array}$} & \multirow{2}{*}{$\begin{array}{l}- \\
+\end{array}$} & \multirow{2}{*}{-} & \multicolumn{3}{|c|}{ Significance } \\
\hline & & & & & & I & $\mathrm{N}$ & $\mathrm{I} \times \mathrm{N}$ \\
\hline \multicolumn{2}{|c|}{ Xylem tension (MPa) } & 0.64 & 1.01 & 1.71 & 2.15 & \multirow{2}{*}{$\begin{array}{l}* * * \\
* * *\end{array}$} & $* * *$ & $* * *$ \\
\hline \multicolumn{2}{|c|}{ Leaf conductance $\left(\mathrm{mol} \cdot \mathrm{m}^{-2} \cdot \mathrm{s}^{-1}\right)$} & 0.251 & 0.080 & 0.030 & 0.021 & & \multirow{2}{*}{$* * *$} & \multirow{2}{*}{$\begin{array}{l}* * * \\
* * *\end{array}$} \\
\hline \multicolumn{2}{|c|}{ Transpiration $\left(\mathrm{mmol} \cdot \mathrm{m}^{-2} \cdot \mathrm{s}^{-1}\right)$} & 6.48 & 2.27 & 0.85 & 0.44 & $* * *$ & & \\
\hline \multicolumn{2}{|c|}{ Total osmolarity (mM) } & 27.0 & 32.0 & 55.0 & 25.0 & NS & $* *$ & $*$ \\
\hline & 2.21 & 2.34 & 4.74 & 2.14 & \multirow{2}{*}{$\begin{array}{l}\mathrm{NS} \\
* * *\end{array}$} & $*$ & NS \\
\hline organic aci & & 0.71 & 1.22 & 2.04 & 2.48 & & NS & NS \\
\hline \multicolumn{2}{|c|}{ Sugars (mM) } & 0.24 & 0.22 & 0.44 & 0.38 & $* *$ & NS & NS \\
\hline \multicolumn{2}{|c|}{ Total organic compounds (mM) } & 3.17 & 3.77 & 7.22 & 5.00 & $* *$ & $*$ & NS \\
\hline \multicolumn{2}{|c|}{ Organic N (mM) } & 3.92 & 4.47 & 9.92 & 4.45 & $*$ & $*$ & NS \\
\hline \multicolumn{2}{|c|}{ Organic $\mathrm{N}: \mathrm{C}$} & 0.267 & 0.253 & 0.286 & 0.174 & NS & \multicolumn{2}{|l|}{ NS } \\
\hline
\end{tabular}

Nonsignificant or significant at $P \leq 0.05,0.01$, or 0.001 , respectively.

ever, application of nutrient solution increased the osmolarity of xylem fluid of $L$. indica. For both species, the sum of the concentration of amino acids, organic acids, and sugars corresponded to $12 \%$ to $15 \%$ of the respective values of total osmolarity with the exception of the water stress treatment $(22 \%$ and $25 \%$ in P. salicina and $L$. indica, respectively) (Tables 1 and 3). Organic acids were the compounds that increased most in xylem fluid from the water stress treatment (Tables 1-4). The concentrations of individual and total amino acids were less influenced by withholding irrigation.

The 2- to 3-fold increases in citric and malic acids for $P$. salicina in the water-stress treatment compared to the well-watered treatment (Table 2) accounted for much of the increase in total organic acids, the increase in total organic compounds quantified, and the reduction in the ratio of organic $\mathrm{N}$ to organic $\mathrm{C}$ (Table 1). By contrast, irrigation did not influence the concentration of total amino acids (Table 1); however, concentrations of aspartic acid, serine, histidine, and phenylalanine increased in response to water stress (Table 2). Arginine was the only amino acid that increased significantly in concentration with application of nutrient solution. The concentrations of sucrose, fructose, and glucose were low (i.e., $\approx 1 \%$ of total osmolarity) and were not significantly altered by irrigation or nutrient solution. Irrigation $\mathrm{x}$ nutrient solution interactions were not significant for any of the variables listed in Table 1 , and few of the individual compounds listed in Table 2.

Plant water relations of $L$. indica were greatly influenced by irrigation, nutrient solution, and irrigation $\times$ nutrient solution interactions (Table 3). Unlike $P$. salicina, L. indica receiving nutrient solution for the duration of the experiment manifested considerably lower $\mathrm{g}_{1}$ and $\mathrm{E}$ compared to the well-watered treatment. Xylem tension, $\mathrm{g}_{1}$, and $\mathrm{E}$ for $L$. indica were significantly influenced by irrigation $\times$ nutrient solution interactions.

Concentration of total organic acids, total sugars, total organic compounds, and organic $\mathrm{N}$ in xylem fluid of $L$. indica all increased by withholding irrigation (Table 3 ). Increased concentrations of amino acids associated with application of nutrient solution was responsible for the increase in total organic compounds (and organic $\mathrm{N}$ ) in xylem fluid. Concentration of total amino acids and organic $\mathrm{N}$ increased 2-fold in the nutrient solution-water-stress treatment (Table 3). The concentration of sugars in xylem fluid of plants not irrigated for 5 days also increased $\approx 2$-fold compared to plants irrigated daily with water or nutrient solution. The ratio of organic $\mathrm{N}$ to organic $\mathrm{C}$ in xylem fluid was dependent on irrigation $\mathrm{x}$ nutrient solution interactions. The $\mathrm{N}$ to $\mathrm{C}$ ratio was particularly low for the water stress treatment.
The concentration of glutamic acid, arginine, alanine, isoleucine, citric acid, malic acid, succinic acid, and glucose in xylem fluid of $L$. indica were influenced by withholding irrigation (Table 4). Malic acid increased from 335 to $2017 \mu \mathrm{M}$ in the water stress treatment. A 6-fold increase in arginine concentration in xylem fluid occurred in plants in the nutrient solution-water-stress treatment. This increase in total amino acids and organic $\mathrm{N}$ can be ascribed mainly to increased $\mathrm{N}$-rich arginine. Irrigation $\times$ nutrient solution interactions occurred for asparagine, aspartic acid, glutamine, serine, and malic and fumaric acid; all compounds except malic acid occurred in low concentration.

\section{Discussion}

The osmolarity of xylem fluid of $P$. salicina was maintained between 26 and $40 \mathrm{~mm}$, despite the application of $138 \mathrm{~mm}$ nutrient solution or with the imposition of severe drought stress that induced nearly complete stomatal closure. The concentration of major plant nutrients in the soil solution is usually in the range of $10^{-6}$ to $10^{-3} \mathrm{M}$ (Clarkson, 1985), or at least two orders of magnitude less than the concentration of soluble nutrients applied in the current study. The osmolarity of xylem fluid of $L$. indica was influenced by nutrient solution, but not by irrigation. For both species, the proportion of the total organic compounds quantified divided by total osmolarity was also relatively constant $(12 \%$ to $15 \%)$ for all except the water-stress treatment (22\% to $25 \%$ for $P$. salicina and $L$. indica, respectively). This regulation of xylem fluid chemistry is consistent with studies showing a minimal influence of fertilization on the chemistry of xylem fluid collected from bleeding plants (Andersen and Brodbeck, 1991; Cooper and Clarkson, 1989; Clark et al., 1986; Roubelakis-Angelakis and Kliewer, 1979). The low concentrations of sugars, particularly sucrose, in xylem fluid of $P$. salicina and $L$. indica are also consistent with previous analyses obtained from bleeding plants, and suggest minimal contamination from phloem fluid or ruptured cells.

Several mechanisms may be responsible for maintaining xylem fluid chemistry within narrowly defined limits. Electrogenic ion pumps, one located at the epidermis-root interface and one located at the plasmalemma-xylem vessel interface (deBoer et al., 1983) regulate nutrients entering xylem vessels (Clarkson, 1985). Perumalla (1986) surveyed 213 angiosperm species from 52 families and found that $88 \%$ of the species had Casparian bands between cortex and stele (endodermis) and in the hypodermis (exodermis). In these species, transport of nutrients from the 


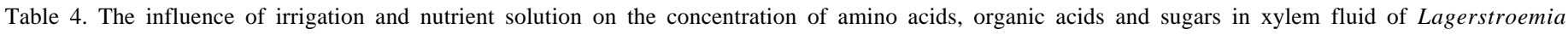
indica. Treatment designation: $+-=$ irrigated with water for 20 days (well-watered treatment); ++ = irrigated with nutrient solution for 20 days (nutrient solution treatment); -+ = nutrient solution for 15 days which was terminated for the final 5 days (nutrient solution/water-stress treatment); -- = irrigated with water for 15 days which was terminated for the final 5 days (water-stress treatment).

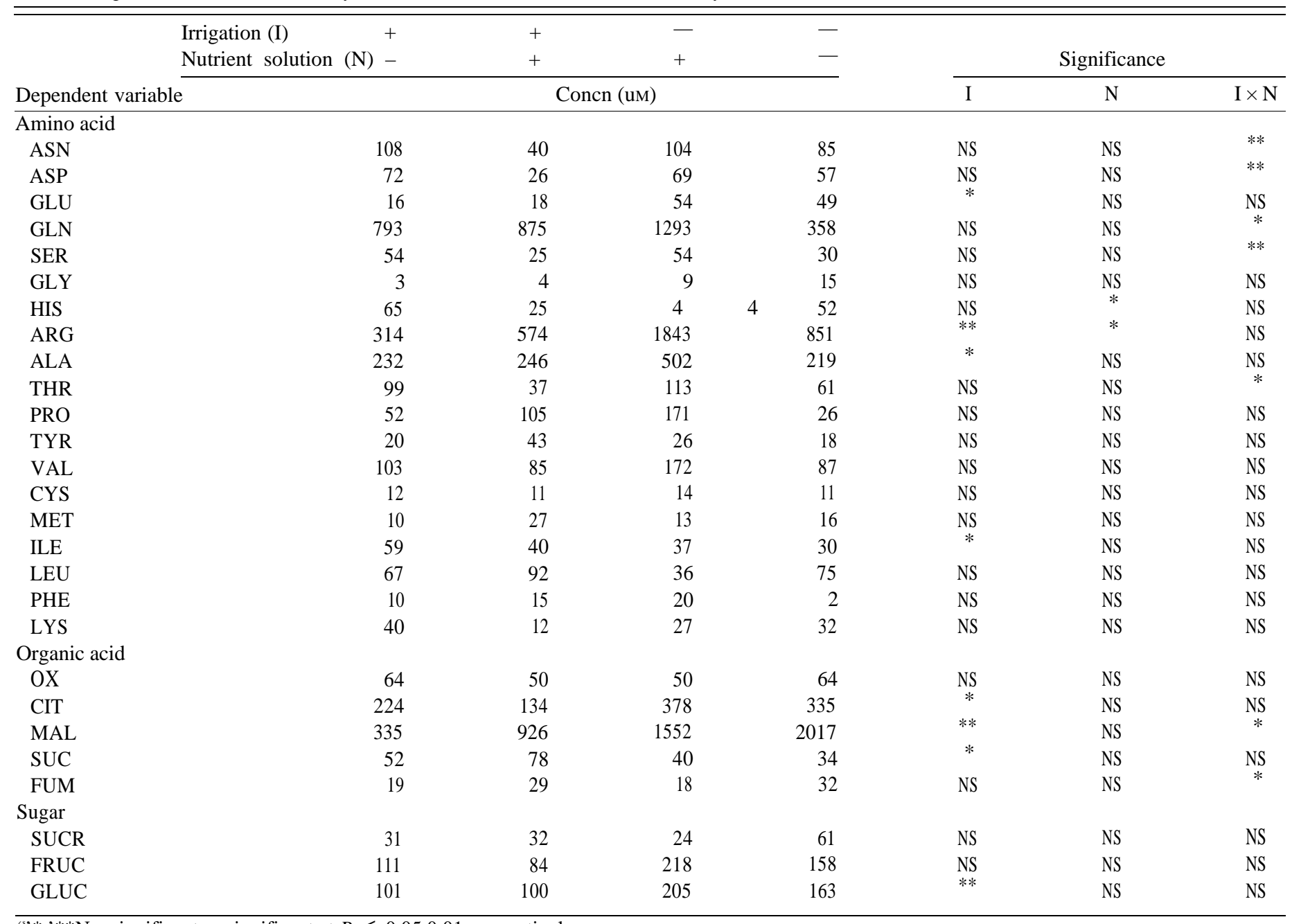

${ }^{s}, *{ }_{* *}$ Nonsignificant or significant at $P \leq 0.05,0.01$, respectively.

epidermis to xylem vessels is symplastic (Peterson, 1988). Cycling of nutrients occurs from shoot to root and from root to shoot via the phloem and xylem, respectively (Cooper and Clarkson, 1989; van Bel, 1990). Cooper and Clarkson (1989) showed that $>60 \%$ of the amino-N in xylem fluid of Triticum aestivum $\mathrm{L}$. represented recycled $\mathrm{N}$. They proposed that a single regulatory pool of amino$\mathrm{N}$ common to both roots and shoots controls $\mathrm{N}$ uptake at the whole plant level. The cytoplasmic concentration of nutrients is also well-buffered by the release-sequestration of nutrients (i.e., $\mathrm{K}+$, $\mathrm{NO}_{3}, \mathrm{Mg}^{2+}$, amino acids) in vacuoles (Bhat, 1982; Clement et al., 1978; Huber-Wachli and Wiemken, 1979; Letey et al., 1982).

Reductions in $\mathrm{g}_{1}$ or $\mathrm{E}$ greatly predominated over changes in xylem chemistry when irrigation was withheld. Given that mass flow of water in xylem vessels can be approximated by measurements of transpiration (Steinberg et al., 1990), for similarly sized plants it follows that the 10 -fold reduction in $\mathrm{g}_{1}$ or $\mathrm{E}$ would correspond to an approximate 10-fold reduction in volume flux to the leaves of water-stressed plants via xylem vessels. Regulation of stomatal aperture during water stress facilitates the maintenance of leaf turgor and reduces water and solute flux in xylem vessels. We propose that the reduction in volume flux in xylem vessels may ameliorate the potential adverse effects of altered chemical profiles of xylem fluid on foliar tissue.
The greatest change in chemical composition in response to water stress occurred in the concentration of organic acids, whereas the amino acids were more stable. Concentrations of organic acids increase in foliar tissue as a consequence of water deficit (Osmond, 1978; Timpa et al., 1986; Venekamp and Koot, 1988). Organic acids accumulate during nitrate reduction (Blevins et al., 1974; Kirkby and Knight, 1977; Wallace et al., 1971) and facilitate ionic balance during excess cation uptake (Triplett et al., 1980; Wallace et al., 1971).

The concentration of free amino acids (particularly proline) often increases markedly in leaves or other plant tissue with exposure to many biotic and abiotic stresses (Boggess et al., 1976; Good and Zaplachinski, 1994; Handa et al., 1986; Naidu et al., 1990; Rabe, 1990; Rainieri et al., 1989; Stewart, 1981; van Rensburg et al., 1993; Voetberg and Sharp, 1991). Proline may represent $1 \%$ of leaf dry matter in many plant species subjected to water stress. For example, 68-and 100-fold increases in proline, were recorded in drought-stressed leaves of Brassica napus (Good and Zaplachinski, 1994) and roots of Zea mays subjected to a water deficit (Voetberg and Sharp, 1991). However, the contribution of proline derived from xylem fluid has seldom been considered. In our study, the concentration of proline in xylem fluid represented a very small fraction of the amino acid profile and did not vary 
significantly as a function of water or fertilization.

Organic acids may be the principal $\mathrm{C}$ source for proline accumulation in drought-stressed plants. Venekamp and Koot (1988) calculated that most of the proline accumulating with drought stress in Vicia faba was via de novo synthesis from organic acids, and not from the hydrolysis of proteins or from preexisting amino acids. Venekamp et al. (1989) demonstrated that organic acids (citric and malic acids, etc.) served as the $\mathrm{C}$ source in the synthesis of proline via glutamate dehydrogenase. The synthesis of proline from organic acids consumes $\mathrm{H}^{+}$and is an efficient mechanism to control cytosolic pH (Venekamp et al., 1989). The importance of the increased concentration of organic acids in xylem fluid occurring in response to water stress to proline synthesis in foliar tissue has not been determined.

The concentration of organic $\mathrm{N}$ in $L$. indica varied with irrigation and nutrient solution. Arginine, the amino acid with the highest $\mathrm{N}$ to $\mathrm{C}$ ratio, increased 6-fold in xylem fluid of plants in the nutrient solution-water-stress treatment. Rabe (1990) proposed that any stress that results in glucose depletion or reduced growth results in increases in $\mathrm{N}$-containing compounds and that the primary role for the accumulation of $\mathrm{N}$-containing compounds reported for numerous environmental stresses (mineral, drought, salinity, temperature, anoxia, $\mathrm{pH}$ ) is $\mathrm{NH}_{4}^{+}$detoxification. Andersen et al. (1989) did not detect $\mathrm{NH}_{4}^{+}$in xylem fluid of $L$. indica (limits of detection $=6 \mu \mathrm{M}$ ) planted in the container medium described in materials and methods, indicating that virtually all $\mathrm{NH}_{4}^{+} \mathrm{was}$ converted to amino compounds before loading in xylem vessels. Application of nutrient solution to $L$. indica was associated with increased water stress as evidenced by increased xylem tension and reduced $g_{1}$ and $E$. These data are consistent with the hypothesis that $L$. indica was experiencing nutrient toxicity. Thus, increased arginine synthesis may have resulted in the detoxification of $\mathrm{NH}_{4}^{+}$.

In conclusion, the chemistry of xylem fluid was well-buffered against changes in water or nutrient content of the rhizosphere. Reductions in solute transport via xylem vessels exceeded changes in the chemical profile with water stress or the application of nutrient solution. Water stress imposed over a 5-day period induced marked reductions in $\mathrm{g}_{\mathrm{l}}$ and $\mathrm{E}$ of both species; however, the influence of the nutrient solution was species dependent. Withholding irrigation and/or the application of nutrient solution (i.e., osmolarity $=138 \mathrm{~mm}$ ) to $P$. salicina did not significantly alter the total osmolarity of xylem fluid. Water stress induced marked changes in the concentration of malic and citric acid in xylem fluid, yet had a relatively minor influence on the concentration of most amino acids. Irrigation and nutrient status influenced plant water relations and the chemical profile of xylem fluid of $L$. indica. The concentration of malic acid, citric acid, and arginine increased most markedly as a function of water stress, or by the application of nutrient solution. Overall, a substantial degree of regulation of xylem fluid chemistry occurred in response to large changes in soil water or nutrient status.

\section{Literature Cited}

Andersen, P.C. and B.V. Brodbeck. 1989a. Diurnal and temporal the chemical profile of xylem exudate from Vitis rotundifolia. Physiol. Plant. 75:63-70.

Andersen, P.C. and B.V. Brodbeck. 1989b. Chemical composition of xylem exudate from bleeding spurs of Vitis rotundifolia Noble and Vitis hybrid Suwannee in relation to pruning date. Amer. J. Enol. Viticult. 40:155-160.

Andersen, P.C. and B.V. Brodbeck. 1989c. Chemical composition of xylem exudate from bleeding spurs of Vitis rotundifolia Noble and Vitis hybrid Suwannee in relation to pruning date. Amer. J. Enol. Viticult. 40:155-160.
Andersen, P.C. and B.V. Brodbeck. 1991. Influence of fertilization on xylem fluid chemistry of Vitis rotundifolia Noble and Vitis Hybrid Suwannee. Amer. J. Enol. Viticult. 42:245-251.

Andersen, P.C., B.V. Brodbeck, and R.F. Mizell, 111.1989. Metabolism of amino acids, organic acids and sugars extracted from the xylem fluid of four host plants by adult Homalodisca coagulata. Entomol. Expt. Applied 50:149-159.

Andersen, P.C., B.V. Brodbeck, and R.F. Mizell, III.1992. Feeding by the leafhopper, Homalodisca coagulata, in relation to xylem fluid chemistry and tension. J. Insect Physiol. 38:611-622.

Andersen, P.C., B.V. Brodbeck, and R.F. Mizell, III. 1993. Diurnal variations of amino acids and organic acids in xylem fluid from Lagerstroemia indica: An endogenous circadian rhythm. Physiol. Plant. 89:783-790.

Berger, A., R. Oren, and E-D Schulze. 1994. Element concentrations in the xylem sap of Picea abies (L.) Karst seedlings by various methods under different environmental conditions. Tree Physiol. 14:111-128.

Bhat, K.K.S. 1982. Nutrient inflows into apple roots. II. Nitrate uptake rates measured on intact roots of mature trees under field conditions. Plant Cell Environ. 5:461-469.

Blevins, D., A.J. Hiatt, and R.H. Lowe. 1974. The influence of nitrate and chloride uptake on expressed sap $\mathrm{pH}$, organic acid synthesis, and potassium accumulation in higher plants. Plant Physiol. 54:82-87.

Boggess, S.F., C.R. Stewart, D.Aspinall, and L.G. Paleg. 1976. Effect of water stress on proline synthesis from radioactive precursors. Plant Physiol. 58:398-404.

Clark, C.J., P.T. Holland, and G.S. Smith. 1986. Chemical composition of bleeding xylem sap from kiwifruit vines. Ann. Bet. 58:353-362.

Clarkson, D.T. 1985. Factors affecting mineral nutrient acquisition by plants. Annu. Rev. Plant Physiol. 36:77-115.

Clement, C. R., M.J. Hopper, and L.H.P. Jones. 1978. The uptake of nitrate by Lolium perenne from flowing culture solution. I. Effect of $\mathrm{NO}_{3}$ concentration. J. Expt. Bet. 29:453-464.

Cooper, H.D. and D.T. Clarkson. 1989. Cycling of amino-nitrogen and other nutrients between shoots and roots in cereals-A possible mechanism integrating shoot and root in the regulation of nutrient uptake. J. Expt. Bet. 40:753-762.

deBoer, A.H., H.B.A. Prins, and P.E. Zanstra. 1983. Biphasic composition of trans-root potential in roots of Plantago species: Involvement of spatially separated electrogenic pumps. Planta 157:259-266.

Good, A.G. and S.T. Zaplachinski. 1994. The effects of drought stress on free amino acid accumulation and protein synthesis in Brassica napus. Physiol. Plant. 90:9-14.

Handa, S., A.K. Handa, P.M. Hasegawa, and R.A. Bressan. 1986. Proline accumulation and the adaptation of cultured plant cells to water stress. Plant Physiol. 80:938-945.

Huber-Wachli, V. and A. Wiemken. 1979. Differential extraction of soluble pools from the cytosol and the vaculoes of yeast (Candida utilis) using DEAE-dextran. Arch. Microbiol. 120:141-149.

Kirkby, E.A. and A.H. Knight. 1977. Influence of the level of nitrate nutrition on ion uptake and assimilation, organic acid accumulation, and cation-anion balance in whole tomato plants. Plant Physiol. 60:349353.

Letey, J., W.M. Jarrell, and N. Valoras. 1982. Nitrogen and water uptake patterns and growth of plants at various minimum solution nitrate concentrations. J. Plant Nutr. 5:73-89.

Naidu, B. P., L.G. Paleg, D. Aspinall, A.C. Jennings, and G.P. Jones. 1990. Rate of imposition of water stress alters the accumulation of nitrogencontaining solutes by wheat seedlings. Austral. J. Plant Physiol. 17:653664.

Osmond, C.B. 1978. Crassulacean acid metabolism: A curiosity in context. Annu. Rev. Plant Physiol. 29:379-414.

Perumalla, C.J. 1986. Studies on the hypodermic of roots and rhizomes of various angiosperm species. PhD diss. Univ. of Waterloo, Waterloo, Ontario, Canada, Univ., Microfilms Internat., Ann Arbor, Mich.

Peterson, C.A. 1988. Exodermal Casparian bands: Their significance for ion uptake by roots. Physiol. Plant. 72:204-208.

Rabe, E. 1990. Stress physiology: The functional significance of the accumulation of nitrogen-containing compounds. J. Hort. Sci. 65:231-243. 
Rainieri, A., R. Bernardi, P. Lanese, and G.F. Soldatini. 1989. Changes in free amino acid content and protein pattern of maize seedlings under water stress. Environ. Expt. Bet. 29:351-357.

Roubelakis-Angelakis, K.A. and W.M. Kliewer. 1979. The composition of bleeding sap from Thompson Seedless grapevines as affected by nitrogen fertilization. Amer. J. Enol. Viticult. 30:14-18.

Scholander, P.F., H.T. Hammel, E.D. Bradstreet, and E.A. Hemmingsen. 1965. Sap pressure in vascular plants. Science 148:339-346.

Steinberg, S. L., M.J. McFarland, and J.W. Worthington. 1990. Comparison of trunk and branch sap flow with canopy transpiration in pecan. J. Expt. Bet. 41:653-659.

Stewart, C.R. 1981. Proline accumulation: biochemical aspects, p. 243 249. In: L.G. Paleg and D. Aspinall (eds.). The physiology and biochemistry of drought resistance in plants. Academic Press, New York.

Timpa, J.D., J.J. Burke, J.E. Quisenberry, and C.W. Wendt. 1986. Effects of water stress on the organic acid and carbohydrate compositions of cotton plants. Plant Physiol. 82:724-728.

Triplett, E.W., N.M. Barnett, and D.G. Blevins. 1980. Organic acids and ionic balance in xylem exudate of wheat during nitrate or sulfate absorption. Plant Physiol. 65:610-613.

van Bel, A.J.E. 1990. Xylem-phloem exchange via the rays: The undervalued route of transport. J. Expt. Bet. 227:631-644.

van Rensburg, L., G.H.J. Kruger, and H. Kruger. 1993. Proline accumulation as drought-tolerance selection criterion: Its relationship to membrane integrity and chloroplast ultrastructure in Nicotiana tabacum L. J. Plant Physiol. 141:188-194.

Venekamp, J.H. and J.T.M. Koot. 1988. The sources of free proline and asparagine in field bean plants, Vicia faba L., during and after a short period of water withholding. J. Plant Physiol. 132:102-109.

Venekamp, J. H., J.E.M. Lampe, and J.T.M. Koot. 1989. Organic acids as sources for drought-induced proline synthesis in field bean plants, Vicia faba L.J. Plant Physiol. 133:654-659.

Voetberg, G.S. and R.E. Sharp. 1991. Growth of the maize primary root at low water potentials. III. Role of increased proline deposition in osmotic adjustment. Plant Physiol. 96:1125-1130.

Wallace, A., A.M. Abou-Zamzam, and E. Motoyama. 1971. Cation and anion balance in the xylem exudate of tobacco roots. Plant and Soil $35: 433-438$ 